\title{
EVALUATION OF PRODUCTION SYSTEMS AND HUSBANDRY PRACTICES OF ETHIOPIAN INDIGENOUS GOATS
}

\author{
Gutu YEMANE ${ }^{1 \times \bowtie}$, Aberra MELESSE², Mestawet TAYE ${ }^{2}$ \\ ${ }^{1}$ Department of Animal Science, Alage ATVET College, P. O. Box 77, Alage, Ethiopia \\ 2School of Animal and Range Sciences, Hawassa University, P. O. Box 05, Hawassa, Ethiopia \\ Email: gutuyemane@gmail.com; (D) ORCID: 0000-0001-7134-7923 \\ supporting Information
}

\begin{abstract}
The study was conducted in Limu Seka, Nono Benja and Omo Nada districts of Jimma zone with the objectives to assess production system and husbandry practices of indigenous goat. Data were collected through questionnaire, focal group discussion and secondary data. A total of 210 households were selected for an interview and case study. Data were analyzed by descriptive statistics and ranking index. The results showed that the overall family size and mean goats flock size per household are 7.10 and 7.78 respectively. The farming activities were mixed crop and livestock systems. Natural pasture (herbs and shrubs), fallow land, crop residues and non-conventional feeds were the feed resources of the study area. Free grazing/browsing, riverside grazing/browsing, aftermath grazing, and herding were the major grazing management types for goats in the dry season. In wet season, grazing management were herding and tethering alone and both herding and tethering together. In the study area, rivers were the main source of water in both dry and rainy season. All households in all the study districts provide nighttime shelter (house) for goat throughout the year. On average about $63.8 \%$ and $61.9 \%$ of respondents have been practicing fattening and castrating goat. Castration was primarily practiced to improve fattening and get a better price. Disease, feed shortage and lack of superior genotypes were major constraints of goat production in the study area. In general, goat production system and husbandry practices in the study area was traditional with mixed livestock system that challenged by serious disease problem and feed shortage, so interference is needed to solve identified problems.
\end{abstract}

Keywords: Indigenous breeds, Husbandry practices, Jimma zone, Rural farming system

\section{INTRODUCTION}

Goat provide multifunctional role and it's the easiest and most readily accessible source of credit available to meet immediate social and financial obligations (Abraham et al., 2017a). Goat production is one of the largest agricultural sectors in developing countries in which Africa shares about 35\% of the world goat population (Skapetas and Bampidis, 2016). Ethiopia has long been renowned as a source of the large diversity of farm animal genetic resources in which 32.74 million goat are reared (CSA, 2018). In the last 10 years, the goat population in Ethiopia increased more rapidly than sheep and cattle populations (FAOSTAT, 2016).

Goats (Capra hircus) have a key role in ensuring food security and economic livelihood to smallholder farmers in rural areas (Monau et al., 2020). Indigenous goats have high significance due to their adaptive traits that are relevant for climate change and low maintenance. Compared to cattle, these genetic resources have become even more important under changing climates (Monau et al., 2020). They are important sources of income and play a vital role as sources of meat and milk for owners in different production systems and agro-ecological zones of Ethiopia. The existing goat populations are adapted to the harsh environmental situation that characterized by low levels of input and technologies, feed scarcity and disease. Goats are managed in low-input, extensive grazing systems based on communal lands and native pastures (Tesfahun et al., 2017; Yemane et al., 2020).

In Ethiopia, various factors could be considered to categorize small ruminant production systems like degree of integration with crop production, contribution to livelihood, level of input and intensity of production, agro-ecology, and length of growing period and relation to land and type of commodity to be produced. In the country goat are kept under traditional extensive systems and raised in two major production systems: mixed crop-livestock and pastoral/agropastoral production systems (Sheriff and Alemayehu, 2018). However, urban and peri-urban production system was also reported in the country. Despite there are large populations of goats, their productivity and the contribution to the country's national economy are low (Solomon et al., 2014). One possible contributing factor for minimal benefit could be the absence of a clear strategy to improve livestock production and productivity in Ethiopia (Chebo and Alemayehu, 2012; Molla, 2020). According to Sheriff and Alemayehu (2018), there is lack of organized and up-to-date information on small 
ruminant production systems in Ethiopia. Defining production system is a base for genetic improvement of farm animals with a sound breeding objective. Farmers in different production systems have different trait preferences due to the varying production activities and available resources (Abraham et al., 2017; 2018).

From the country's total goat populations, Oromia regional state had 8.59 million heads of goat (CSA, 2018). As the study area, Jimma zone share large goat population in which goats play a major role for the smallholder farmers. Despite their importance, information provided on goat production system and husbandry practices specific to the study districts was very few till yet. Accordingly, assessing these goat production systems is vital to deliver documented information and it is a pre-requisite for proper breeding program. Therefore, this study was assessed to identify goat production systems and husbandry practices in the study area.

\section{MATERIALS AND METHODS}

The current study was conducted in three districts (Limu Seka, Nono Benja and Omo Nada) of Jimma zone, Oromia Regional State of Ethiopia. The zone lies between $35^{\circ}-37^{-} \mathrm{E}$ longitudes and $7^{0}-8^{0^{-}} \mathrm{N}$ latitude at an elevation ranging from 880 to 3360 meters above sea level.

\section{Sampling and data collection procedures}

Multi-stage sampling techniques were applied to select districts and kebeles for the study. At the first stage out of the twenty districts, three districts (Limu Seka, Omo Nada and Nono Benja) were purposively selected based on their goat population potential. In the second stage, four, three and two kebeles were purposively and proportionally selected from Limu Seka, Omo Nada and Nono Benja districts, respectively. Moreover, care was taken to select representative sample size by considering goat flock size of at least two females and one male goat per household and willingness of households to participate in the study. In the third stage, the number of households from each selected kebeles was determined according to the proportionate sampling technique. The sample size of $\mathbf{2 1 0}$ households was determined according to the Arsham (2007), using the following formula: $N=0.25 / \mathrm{SE}^{2}$ where: $\mathrm{N}=$ sample size, $\mathrm{SE}=$ standard error (0.0345) with $95 \%$ confidence level. In the sampling process, households those keep at least three matured goats were considered. Accordingly, one focal group discussion was held per kebele including key informants. In the study, both primary and secondary data were used.

\section{Questionnaires and group discussion}

General information list of FAO (2012), was used as a checklist in designing the questionnaire. Trained enumerators along with the researcher administrated the semi-structured questionnaires to the sampled households. General information of the area, topography, climatic data, and population size were obtained from secondary data. Participatory focus group discussion with goat owners, elderly farmers, village leaders were also made. The questionnaire was designed to address the description of the production environment (general household characteristics, goat flock size and farming activities) and goat husbandry practices like feeding, watering, housing, castration and fattening practices of households in the study area were assessed. Moreover, constraints of goat production were also assessed.

\section{RESULTS}

\section{General household characteristics}

The family size, household age, sex, educational level, age structure and marital statuses of households in the study districts are presented in Table 1. The overall family size in the study area is 7.10. There was a significant difference $(P<0.05)$ in the average family size of respondents between districts. Average family size was significantly higher in 0 mo Nada district than Nono Benja and Limu Seka districts. The overall households' age in the study area was 44.89 years with majority $(90.5 \%)$ of the households were male headed. In the study area, the sampled households had different educational backgrounds in which majority (73.8\%) of them were illiterate. A higher proportion of the households ranged within an age of 31 to 40 years (44.3\%). The study further revealed that the majority (91.4\%) of the respondents were married.

\section{Goat flock size and farming activities}

The current result showed that all respondents across all districts were practicing both livestock and crop production. The overall mean goats flock size per household was 7.78 (Table 2). There was a significant difference between districts in goat population $(P<0.05)$. Respondents in Nono Benja had significantly lower number of goats than Omo Nada and Limu Seka districts. There was significant difference between districts $(P<0.05)$ on the suckling male kid, weaned male kid less than one year and castrated goat which was higher in Limu Seka district. In the study area, males accounted for about $30.2 \%$ and females $69.8 \%$ of the total flock. In the study area, matured female greater than one year constituted $43.8 \%$ of the whole population while matured males of the same age were only $7.2 \%$ of the population. The ratio between matured male greater than one-year age and their female counterparts was accordingly 1:6. 
Table 1 - General household characteristics

\begin{tabular}{|c|c|c|c|c|}
\hline HH characteristics & Limu Seka & Nono Benja & Omo Nada & Overall \\
\hline Family size (Mean $\pm S E)$ & $6.72 \pm 0.13^{a}$ & $7.28 \pm 0.21^{\mathrm{ab}}$ & $7.48 \pm 0.16^{b}$ & $7.10 \pm 0.09$ \\
\hline Age (Mean \pm SE) & $44.12 \pm 0.65$ & $45.15 \pm 0.87$ & $45.75 \pm 0.84$ & $44.89 \pm 0.44$ \\
\hline & $\mathbf{N}$ (\%) & $\mathbf{N}$ (\%) & $\mathbf{N}(\%)$ & $\mathbf{N}(\%)$ \\
\hline \multicolumn{5}{|l|}{ Sex } \\
\hline Male & $85 *(90.4)$ & $42 *(91.3)$ & $63 *(90)$ & $190 *(90.5)$ \\
\hline Female & $9(9.6)$ & $4(8.7)$ & $7(10)$ & 20(9.5) \\
\hline $\mathrm{X}^{2}$-value & 61.44 & 31.39 & 44.80 & 137.62 \\
\hline \multicolumn{5}{|l|}{ Educational status } \\
\hline Illiterate & $68 *(72.3)$ & $32 *(69.6)$ & $55 *(78.6)$ & $155 *(73.8)$ \\
\hline Elementary (1-8) & $24(25.5)$ & 14(30.4) & $13(18.6)$ & $51(24.3)$ \\
\hline Secondary $(9-10)$ & $2(2.1)$ & - & $2(2.9)$ & $4(1.9)$ \\
\hline $\mathrm{X}^{2}$-value & 37.66 & 3.43 & 21.77 & 73.35 \\
\hline \multicolumn{5}{|l|}{ Age structure (year) } \\
\hline$\leq 30$ & $4(4.3)$ & - & $3(4.3)$ & $7(3.3)$ \\
\hline $31-40$ & $42 *(44.7)$ & $21(45.7)$ & $30 *(42.9)$ & $93 *(44.3)$ \\
\hline $41-50$ & $33(35.1)$ & 14(30.4) & $16(22.9)$ & $63(30)$ \\
\hline$>50$ & $15(16)$ & 11(23.9) & $21(30)$ & $47(22.4)$ \\
\hline $\mathrm{X}^{2}$-value & 72.08 & 7.04 & 67.05 & 170.60 \\
\hline \multicolumn{5}{|l|}{ Marital status } \\
\hline Married & $87 *(92.6)$ & $42 *(91.3)$ & $63 *(90)$ & $192 *(91.4)$ \\
\hline Widowed & $7(7.4)$ & $4(8.7)$ & $7(10)$ & $18(8.6)$ \\
\hline $\mathrm{X}^{2}$-value & 68.08 & 31.39 & 44.80 & 144.17 \\
\hline
\end{tabular}

\section{Table 2 - Average number of goat with their respective age category (Mean \pm SE)}

\begin{tabular}{llccc} 
Goat age category & Limu Seka & Nono Benja & Omo Nada & Overall \\
\hline Total goat & $8.35 \pm 3.06^{\mathrm{b}}$ & $6.56 \pm 1.9^{\mathrm{a}}$ & $7.81 \pm 2.57^{\mathrm{b}}$ & $7.78 \pm 2.76$ \\
Suckling male kid & $0.81 \pm 0.08^{\mathrm{b}}$ & $0.41 \pm 0.09^{\mathrm{a}}$ & $0.77 \pm 0.09^{\mathrm{b}}$ & $0.71 \pm 0.05$ \\
Suckling female kid & $1.42 \pm 0.12^{\mathrm{a}}$ & $1.10 \pm 0.09^{\mathrm{a}}$ & $1.37 \pm 0.10^{\mathrm{a}}$ & $1.33 \pm 0.06$ \\
Weaned male kid (<1 year) & $0.78 \pm 0.07^{\mathrm{b}}$ & $0.36 \pm 0.07^{\mathrm{a}}$ & $0.58 \pm 0.08^{\mathrm{ab}}$ & $0.62 \pm 0.04$ \\
Weaned female kid (<1 year) & $0.69 \pm 0.06^{\mathrm{a}}$ & $0.52 \pm 0.11^{\mathrm{a}}$ & $0.77 \pm 0.07^{\mathrm{a}}$ & $0.68 \pm 0.04$ \\
Matured male $(>1$ year) & $0.60 \pm 0.06^{\mathrm{a}}$ & $0.47 \pm 0.08^{\mathrm{a}}$ & $0.55 \pm 0.07^{\mathrm{a}}$ & $0.56 \pm 0.04$ \\
Matured female (> 1 year) & $3.46 \pm 0.08^{\mathrm{a}}$ & $3.43 \pm 0.10^{\mathrm{a}}$ & $3.31 \pm 0.10^{\mathrm{a}}$ & $3.40 \pm 0.05$ \\
Castrated & $0.55 \pm 0.05^{\mathrm{b}}$ & $0.23 \pm 0.06^{\mathrm{a}}$ & $0.44 \pm 0.05^{\mathrm{ab}}$ & $0.44 \pm 0.03$ \\
\hline a-b Different superscript letters within a row denote significant differences at P<0.05 & & &
\end{tabular}

\section{Goat husbandry practices}

Feed source and feeding management. The current study showed that the availability of feed resources depends on seasonal factors (Table 3). The feed resources of the study area were natural pasture especially herbs and shrubs, fallow land, crop residues and non-conventional feeds (household and Chat leftovers, atella of tella and areke). During the dry season, when feed scarcity is the main problem, farmers provide different supplements to their animals. The supplements that are provided to goats were homemade feed; non-conventional feeds like households and Chat (Catha edulis) leftovers, atella of tella and areke that are the byproducts of locally made beverages; common salt; and crop residues of maize, teff, and sorghum. Grazing management practiced in the study area depended on the season of the year. Free grazing/browsing, riverside grazing/browsing, aftermath grazing, and herding were the major grazing management types for goats in the dry season. In wet season, grazing management were herding and tethering alone and both herding and tethering together. In wet season, grazing management types was significantly different between districts $(P<0.05)$. $A$ higher proportion (65.2\%) of respondents in Nono Benja district practiced herding only. As a whole, in wet season $51.4 \%$, $19.5 \%$ and $29 \%$ of the households practiced herding, tethering, and herding and tethering together, respectively. Aftermath and riverside browsing are an important source of goat feed from the start of the dry season to the start of the short rainy season, after which their importance declines in case of aftermath.

\section{Water source and watering system}

The main sources of water in the study area are rivers, springs, rainwater, water wells, and pond though their importance was unlike in different seasons. In all study districts, rivers were the main source of water in both dry and rainy season (Table 4). Source of water in both dry and rainy season showed a significant difference between districts at $P<0.001$. In Limu Seka and Nono Benja districts none of the households responded dam or ponds as a source of water but in Omo Nada $\mathbf{2 4 . 3 \%}$ of households in the rainy season and $42.9 \%$ in dry season use dam as a source of water. Majority of the respondents in the study area are traveling a distance of 1-5 km to get a watering point during both in 
rainy $(61.4 \%)$ and dry seasons (54.3\%) while more respondents $(40 \%)$ in Omo Nada district go a long distance (6-10 $\mathrm{km})$ during the dry season. The watering frequency in the study area was different from season to season (Table 4). During rainy season, the majority $(\mathbf{7 7 . 6 \% )}$ of respondents watered goats freely and about $(\mathbf{2 2 . 4 \% )}$ were watered once in a day. In contrast, during dry season goats were watered once in a day (52.9\%), followed by once in two days (47.1\%). However, more $(57.1 \%)$ respondents in Omo Nada water their goat once in two days.

Table 3 - Feed resources and grazing management during different seasons.

\begin{tabular}{|c|c|c|c|c|c|}
\hline Feed resources & $\begin{array}{c}\text { Limu Seka } \\
\text { N (\%) }\end{array}$ & $\begin{array}{c}\text { Nono Benja } \\
\text { N (\%) }\end{array}$ & $\begin{array}{c}\text { Omo Nada } \\
\text { N (\%) }\end{array}$ & $\begin{array}{l}\text { Overall } \\
\mathrm{N}(\%)\end{array}$ & $\mathbf{X}^{2}$ \\
\hline \multicolumn{6}{|l|}{ Dry season } \\
\hline Natural pasture only & $17(18.1)$ & $10(21.7)$ & 12(17.1) & $39(18.6)$ & \\
\hline Fallow land +Natural pasture $+\mathrm{CA}+\mathrm{CR}$ & $67(71.3)$ & $27(58.7)$ & 47(67.1) & $141(67.1)$ & \\
\hline Non-conventional feeds & 10(10.6) & $9(19.6)$ & 11(15.7) & $30(14.3)$ & $2.94^{\text {ns }}$ \\
\hline \multicolumn{6}{|l|}{ Wet season } \\
\hline Natural pasture only & 45(47.9) & $27(58.7)$ & $36(51.4)$ & $108(51.4)$ & \\
\hline Fallow land+Natural pasture + Non-conventional feeds & $49(52.1)$ & 19(41.3) & $34(48.6)$ & 102(48.6) & $1.45^{\mathrm{ns}}$ \\
\hline \multicolumn{6}{|l|}{ Grazing management type } \\
\hline \multicolumn{6}{|l|}{ Dry season } \\
\hline Free grazing/browsing & $47(50)$ & $25(54.3)$ & 40(57.1) & $112(53.3)$ & \\
\hline River side grazing/browsing & $16(17)$ & $7(15.2)$ & $10(14.3)$ & $33(15.7)$ & \\
\hline Stubble/aftermath grazing & $21(22.3)$ & $6(13)$ & 12(17.1) & $39(18.6)$ & \\
\hline Herding & $10(10.6)$ & $8(17.4)$ & $8(11.4)$ & $26(12.4)$ & $3.36^{n s}$ \\
\hline \multicolumn{6}{|l|}{ Wet season } \\
\hline Herding only & $46(48.9)$ & $30(65.2)$ & $32(45.7)$ & $108(51.4)$ & \\
\hline Tethering only & $14(14.9)$ & $5(10.9)$ & $22(31.4)$ & 41(19.5) & \\
\hline Herding and tethering & $34(36.2)$ & $11(23.9)$ & $16(22.9)$ & $61(29)$ & $13.12^{*}$ \\
\hline
\end{tabular}

Table 4 - Water source, frequency of watering and distance to nearest watering point

\begin{tabular}{|c|c|c|c|c|c|c|c|c|}
\hline \multirow{2}{*}{ Variables } & \multicolumn{2}{|c|}{ Limu Seka (\%) } & \multicolumn{2}{|c|}{ Nono Benja (\%) } & \multicolumn{2}{|c|}{ Omo Nada (\%) } & \multicolumn{2}{|c|}{ Overall (\%) } \\
\hline & RS & DS & RS & DS & RS & DS & RS & DS \\
\hline \multicolumn{9}{|l|}{ Source of water } \\
\hline Dam/pond & - & - & - & - & 24.3 & 42.9 & 8.1 & 14.3 \\
\hline River & 63.8 & 76.6 & 67.4 & 89.1 & 44.3 & 44.3 & 58.1 & 68.6 \\
\hline Spring & 21.3 & 6.4 & 13 & 6.5 & 2.9 & 4.3 & 13.3 & 5.7 \\
\hline Rain water & 14.9 & - & 19.6 & - & 28.6 & - & 20.5 & - \\
\hline Water well & - & 17 & - & 4.3 & - & 8.6 & - & 11.4 \\
\hline $\mathrm{X}^{2}$ value & & & & & & & $51.41^{* * *}$ & $75.2^{* * *}$ \\
\hline \multicolumn{9}{|l|}{ DNWP } \\
\hline Watered at home & 7.4 & 6.4 & 6.5 & 6.5 & 12.9 & 10 & 9 & 7.6 \\
\hline$<1 \mathrm{~km}$ & 26.6 & 12.8 & 23.9 & 6.5 & 24.3 & 7.1 & 25.2 & 9.5 \\
\hline $1-5 \mathrm{~km}$ & 60.6 & 54.3 & 65.2 & 71.7 & 60 & 42.9 & 61.4 & 54.3 \\
\hline $6-10 \mathrm{~km}$ & 5.3 & 26.6 & 4.3 & 15.2 & 2.9 & 40 & 4.3 & 28.6 \\
\hline $\mathrm{X}^{2}$ value & & & & & & & $2.55^{\mathrm{ns}}$ & 13.14 * \\
\hline \multicolumn{9}{|l|}{ FW } \\
\hline Freely available & 73.4 & - & 80.4 & - & 81.4 & - & 77.6 & - \\
\hline Once a day & 26.6 & 56.4 & 19.6 & 60.9 & 18.6 & 42.9 & 22.4 & 52.9 \\
\hline Once in 2 days & - & 43.6 & - & 39.1 & - & 57.1 & - & 47.1 \\
\hline $\mathrm{X}^{2}$ value & & & & & & & $1.75^{\text {ns }}$ & $4.46^{\mathrm{ns}}$ \\
\hline
\end{tabular}

\section{Housing system}

All households in all the study districts provide nighttime shelter for goat throughout the year to protect them from predators (Table 5). Majority (66.2\%) of farmers kept their goat in a separate house with a roof at night, while $22.4 \%$ of them kept goats inside their family house and $11.4 \%$ kept goat in a house that is attached to the main family house (adjoin house) and shares family house roof externally. About $59 \%$ and $41 \%$ of the households responded that goat house's roof was constructed from iron sheet and grass, respectively while the wall was constructed from wood and the floor was from soil (earth). The majority of walls were made up of Eucalyptus trees that are abundantly available in the study areas. Majority of goat (63.8\%) were housed with sheep and calves while $36.2 \%$ were housed alone, but none of the households responded with equines and cattle in the same house. 


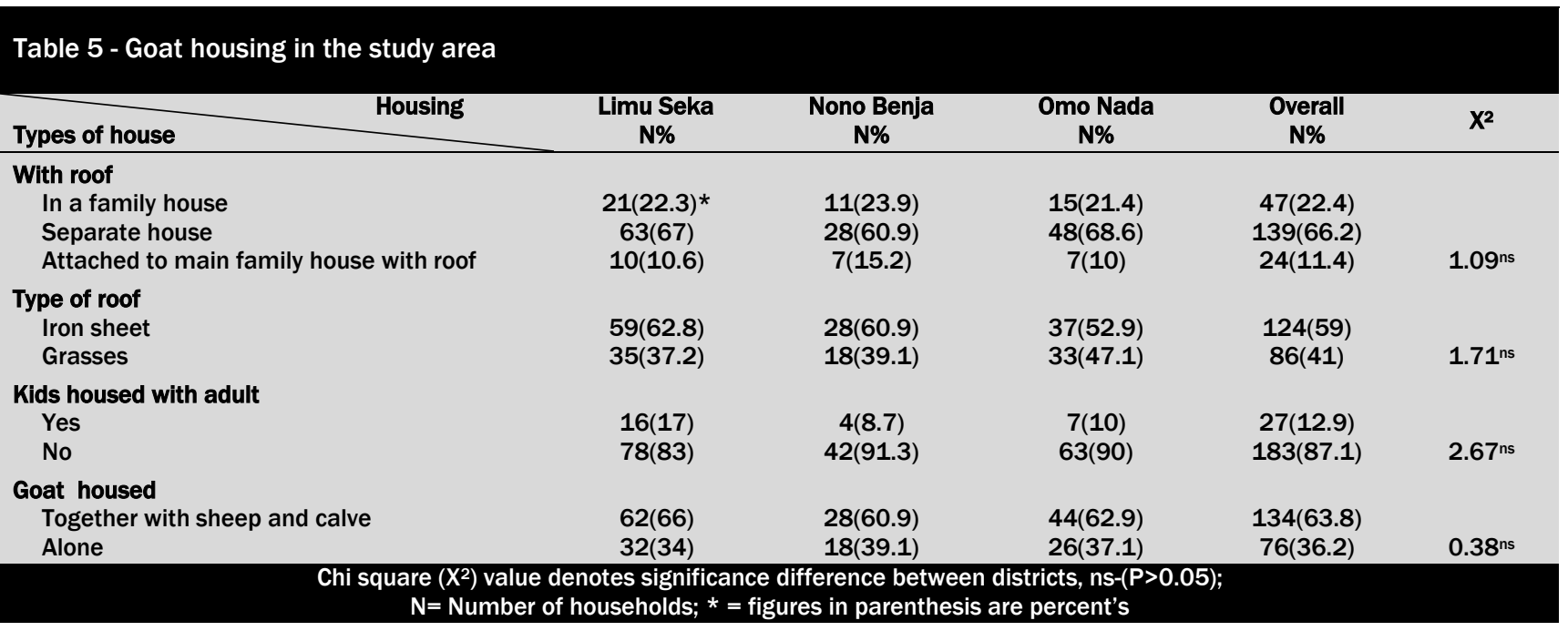

\section{Fattening practices}

Fattening practices of goats in the study districts is presented in Table 6. Goat fattening practice was significantly $(\mathrm{P}<0.05)$ different among districts. In the study area, on average about $63.8 \%$ of respondents have been practicing goat fattening. Majority of farmers in Limu Seka (73.4\%) and Omo Nada (61.4\%) districts fatten goat, while only about $47.8 \%$ of respondents in Nono Benja were fattening goat. Respondents in the study area were fattening different categories of goats. Majority of them (53.8\%) fatten young male, castrates and older males. Females were fattened when they get older or when they stopped giving birth, otherwise, they kept for breeding to produce replacement flock. Types of feed resources given to fattening goat was significantly different between districts $(P<0.05)$. Feed resources used for fattening were natural pasture, crop residues, homemade boiled grain of maize and bean, household leftovers, chat leftover (Gheraba), local brewery residues (atella of areke and tella), mill house by product and porridge (the heated thick mixture of maize, barley and bean powder with water). Utilization of porridge as feed resource was reported only by goat milk users in Limu Seka district because they use it especially to fatten castrated goat and for milking does. Fattening was practiced both during the wet and dry seasons. About $55 \%$ of the respondents reported that duration of fattening goats is about 4-6 months while $29.7 \%$ of the respondents reported that until they were fattened with no time limit.

Table 6 - Fattening practices of goats in the three districts

\begin{tabular}{|c|c|c|c|c|c|}
\hline Variables & $\begin{array}{c}\text { Limu Seka } \\
\mathbf{N} \%\end{array}$ & $\begin{array}{c}\text { Nono Benja } \\
\text { N\% }\end{array}$ & $\begin{array}{c}\text { Omo Nada } \\
\text { N\% }\end{array}$ & $\begin{array}{c}\text { Overall } \\
\text { N\% }\end{array}$ & $\mathbf{X}^{2}$ \\
\hline \multicolumn{6}{|l|}{ Goat fattening } \\
\hline Yes & $69(73.4)^{1}$ & $22(47.8)$ & $43(61.4)$ & 134(63.8) & \\
\hline No & $25(26.6)$ & $24(52.2)$ & $27(38.6)$ & $76(36.2)$ & $9.01 *$ \\
\hline \multicolumn{6}{|l|}{ Categories of animals fattening } \\
\hline Young male + Castrates + Older male & $39(52)$ & $13(50)$ & 26(59.1) & $78(53.8)$ & \\
\hline Culled young male + Older female & 14(18.7) & $7(26.9)$ & $4(9.1)$ & $25(17.2)$ & \\
\hline Castrates + Older males only & 22(29.3) & $6(23.1)$ & $14(31.8)$ & $42(29)$ & $3.98^{\text {ns }}$ \\
\hline \multicolumn{6}{|l|}{ Types of feed for fattening } \\
\hline NP only & $32(42.7)$ & $7(26.9)$ & 15(34.1) & $54(37.2)$ & \\
\hline NP + Boiled maize grain, sorghum and bean & $12(16)$ & $9(34.6)$ & $9(20.5)$ & $30(20.7)$ & \\
\hline $\mathrm{NP}+\mathrm{HL}+\mathrm{CL}+\mathrm{LBR}$ & 11(14.7) & $6(23.1)$ & $15(34.1)$ & $32(22.1)$ & \\
\hline NP + Mill house by product & $9(12))$ & $4(15.4)$ & $5(11.4)$ & $18(12.4)$ & \\
\hline NP + CR+ Porridge & 11(14.7) & - & - & $11(7.6)$ & 19.94 * \\
\hline \multicolumn{6}{|l|}{ Season of fattening } \\
\hline Dry season & 25(33.3) & $8(30.8)$ & 18(40.9) & $56(35.2)$ & \\
\hline Wet season & $50(66.7)$ & $18(69.2)$ & $26(59.1)$ & $89(64.8)$ & $0.96^{\text {ns }}$ \\
\hline \multicolumn{6}{|l|}{ Duration of fattening } \\
\hline Until they get fattened & $21(28)$ & $8(30.8)$ & 14(31.8) & $43(29.7)$ & \\
\hline 4-6 months & $44(58.7)$ & 14(53.8) & $21(47.7)$ & $79(54.5)$ & \\
\hline$>6$ months & 10(13.3) & $4(15.4)$ & $9(20.5)$ & $23(15.9)$ & $1.65^{\text {ns }}$ \\
\hline
\end{tabular}

\section{Castration practices}

Goat's castration practice in the study area is showed in Table 7. On average about $61.9 \%$ of respondents, castrate goats. Castration practice was significantly different between districts $(P<0.05)$. In Limu Seka and Omo Nada district, about $70.2 \%$ and $60 \%$ of farmers practiced goat castration, while in Nono Benja only $47.8 \%$ of them castrate their goat. About $54.6 \%$ of the respondents were performing modern type of castration procedure at a veterinary clinic by using Burdizo castrator, while $\mathbf{4 5 . 4 \%}$ were practicing traditional methods. In the traditional method, goats were castrated by experienced farmers using material like iron hammer and stone. Castration was primarily practiced to improve fattening 
and get a better price (81.5\%). In all districts, the reported age of castration was from $6-18$ months and $>18$ months; however, the majority (64.6\%) of respondents practiced at the age of 12-18 months. Among farmers, those practiced castration; about $89 \%$ of them provided a supplement for their goat. Once they castrate goat, they feed for different lengths of time. About $53 \%$ and $47 \%$ of farmers supplement their goat for 4-6 months and greater than 6 months, respectively.

\section{Constraints of goat production}

In the study area as reported by respondents, the three primary constraints of goat production were disease, feed shortage and lack of superior genotype with an index of $0.36,0.258$ and 0.201 , respectively.

\begin{tabular}{|c|c|c|c|c|c|}
\hline Variables & $\begin{array}{c}\text { Limu Seka } \\
\text { N\% }\end{array}$ & $\begin{array}{c}\text { Nono Benja } \\
\text { N\% }\end{array}$ & $\begin{array}{c}\text { Omo Nada } \\
\text { N\% }\end{array}$ & $\begin{array}{c}\text { Overall } \\
\mathrm{N} \%\end{array}$ & $\mathrm{X}^{2}$ \\
\hline \multicolumn{6}{|l|}{ Castration practice } \\
\hline Yes & $66(70.2)^{1}$ & $22(47.8)$ & $42(60)$ & $130(61.9)$ & \\
\hline No & $28(29.8)$ & 24(52.2) & $28(40)$ & $80(38.1)$ & $6.72^{*}$ \\
\hline \multicolumn{6}{|l|}{ Castration method } \\
\hline Traditional & 29(43.9) & 12(54.5) & $18(42.9)$ & $59(45.4)$ & \\
\hline Modern & $37(56.1)$ & $10(45.5)$ & $24(57.1)$ & $71(54.6)$ & $0.91^{\mathrm{ns}}$ \\
\hline \multicolumn{6}{|l|}{ Reasons for castration } \\
\hline Improve fattening and better price & $56(84.8)$ & 16(72.7) & $34(81)$ & $106(81.5)$ & \\
\hline Control breeding & $4(6.1)$ & $3(13.6)$ & $3(7.1)$ & $10(7.7)$ & \\
\hline Reduce aggressiveness & $6(9.1)$ & $3(13.6)$ & $5(11.9)$ & $14(10.8)$ & $1.95^{\mathrm{ns}}$ \\
\hline \multicolumn{6}{|l|}{ Age of castration } \\
\hline 6- 12 months & 12(18.2) & $7(31.8)$ & $10(23.8)$ & 29(22.3) & \\
\hline 12- 18 months & $46(69.7)$ & $11(50)$ & $27(64.3)$ & $84(64.6)$ & \\
\hline$>18$ months & $8(12.1)$ & 4(18.2) & $5(11.9)$ & 17(13.1) & $2.96^{\mathrm{ns}}$ \\
\hline \multicolumn{6}{|l|}{ Supplementation of castrated goat } \\
\hline Yes & 61(92.4) & 18(81.8) & $37(88.1)$ & $116(89.2)$ & \\
\hline No & $5(7.6)$ & 4(18.2) & $5(11.9)$ & $14(10.8)$ & $2.01^{\mathrm{ns}}$ \\
\hline \multicolumn{6}{|l|}{ Length of supplementation } \\
\hline 4-6 month & $36(59)$ & 10(58.8) & 15(40.5) & 61(53) & \\
\hline$>6$ month & 25(41) & $7(41.2)$ & 22(59.5) & $54(47)$ & $3.42^{\mathrm{ns}}$ \\
\hline
\end{tabular}

\section{Table 8 - Constraints of goat production in the study area prioritized using index values}

\begin{tabular}{|c|c|c|c|c|}
\hline Constraints & Limu Seka & Nono Benja & Omo Nada & Overall \\
\hline Water shortage & 0.142 & 0.145 & 0.162 & 0.150 \\
\hline Feed shortage & 0.259 & 0.243 & 0.267 & 0.258 \\
\hline Lack of superior genotypes & 0.207 & 0.207 & 0.188 & 0.201 \\
\hline Disease & 0.349 & 0.366 & 0.367 & 0.360 \\
\hline Market & 0.004 & 0.004 & - & 0.002 \\
\hline Predator & 0.011 & - & - & 0.005 \\
\hline Thief & 0.007 & - & 0.017 & 0.009 \\
\hline Poor veterinary service & 0.014 & 0.022 & - & 0.011 \\
\hline Limited extension service & 0.007 & 0.014 & - & 0.006 \\
\hline
\end{tabular}

\section{DISCUSSION}

\section{General household characteristics}

The overall family size in the current study corroborate with Yadeta (2016) in west Shoa of Oromia region who reported 7.1; but was higher than that of Alubel (2015) who reported 6.8 in Ziquala, Tanqua Abergelle and Lay Armachiho districts. The overall households' age in the study area was consistent with that of Mohammed et al. (2016), who reported 45.32 years in Jimma zone of southwest Ethiopia. Male that could be due to female's workload inside the house dominated the majority of the households and men play a leading role in decision-making. The current result was slightly lower than that of Teshager et al. (2013) who reported male dominated HH heads (95.6\%) in Ilu Aba Bora zone. The sampled households had different educational backgrounds in which majority of them were illiterate. However, the result was lower than Mohammed et al. (2016) who reported $80 \%$ of illiteracy in Jimma zone, which may indicate improvement through the existence of farmers training center in their specific kebeles. The community is in high productive age group and contributes more for goat production. 


\section{Goat flock size and farming activities}

Farming activities in the study area are characterized by mixed crop and livestock system. Similar findings have been reported by Tegegn et al. (2016) in Bench Maji zone; Yadeta (2016) in West Shoa of Oromia region; Abraham et al. (2017a) in western Tigray; Beyene et al. (2018) in Dawuro zone of Ethiopia. The relative higher goat flock size in Limu Seka indicates the importance of goat production and a strong opportunity for breeding activities in the district. The overall mean goats flock size per household in the study area was higher than that of Dhaba et al. (2012) and Beyene et al. (2018) who reported 3.99 in Ilu Aba Bora and 5.69 flock sizes in Dawuro zones, respectively, that may be due to the varying management activities and available resources. However, the current finding is lower than the report of Alefe (2014) in Shebelle zone, Tsigabu (2015) in Nuer zone, Belete et al. (2015) in Bale zone and Tegegn et al. (2016) in Bench Maji zone of Ethiopia who reported 37.65, 16.9, 13.5 and 9.8 goat flock size per household, respectively. The current result indicates that the goat flock size in the study area was small which might be resulted from farmers raise goats and other livestock species with crop production that enforce them not to keep large flock due to population growth and decreasing grazing/browsing land as a result of increasing ploughing land for crop production. The current finding agreed with that of Tegegn et al. (2016), Tegegn, and Askale (2017) who reported small goat flock size in the mixed croplivestock production systems. Focus group discussion revealed that males were castrated at an early age for fattening to fetch better price and to reduce aggressiveness that makes management simpler. They are also sold at an early age than females and slaughtered for home consumption, although some bucks were kept for breeding. As a result, the numbers of male goats become smaller. Tegegn and Askale (2017) also reported smaller proportion of males (36.4\%) and larger proportion of females (63.6\%). Male to female ratio of this finding was slightly higher than the report of Alubel (2015) with 1:4-1:5 for Abergelle and Central highland goats and; lower than the report of Abegaz (2014) with 1:7 and 1:12 for Western Lowland and Abergelle goats, respectively, and Belete et al. (2015) with 1:8 in Bale zone.

\section{Goat husbandry practices}

\section{Feed source and feeding management}

The use of natural pasture (shrubs and herds) as feed source may be due to goat's preference to browse herbs and leaf of small trees than fibrous feed especially during dry period. The type of animal feed under the current study is similar with the reports of Mohammed et al. (2016) in Jimma zone of Oromia region, Shewangzaw et al. (2018) in Amhara region and Beyene et al. (2018) who reported natural pasture, fallow land, crop residues and non-conventional feeds are the common feed resources in their studied areas. Grazing/browsing management in the study area bespeaks that goats are under controlled feeding and close supervision in wet season by herders, and tethered for the purpose of avoiding crop and vegetation damage, saving labor and protecting from predators. The result concurs with Dhaba et al. (2012) and Arse et al. (2013) who reported tethered feeding. According to focal group discussion, feed shortage occurs during the dry season of the year. The major feed shortage months extend from mid-November up to April, while in some years it can goes up to May.

\section{Water source and watering system}

Similar with the current result, Alubel (2015) and Shewangzaw et al. (2018) reported that rivers as the most important sources of water during dry and wet seasons. During group discussions, respondents were reported that in dry season water shortage has occurred in all study areas and kids of less than 1 month watered at home. The reason was kids are not able to move long distance with an adult that was also reported by Alubel (2015). The current result implies that water is freely available in rainy season due to rain. On the other hand, 1-2 days of watering is common in dry season that is explained due to shortage of water in dry season that resulted from springs and some small rivers got dried off. Similarly, Alubel (2015) and Yadeta (2016) reported free access to water during wet season and in the dry season watered either once in a day or once in two days. The current study disagreed with that of Belete et al. (2020) in Bale zone and Alefe (2014) in Shebelle zone of southeastern Ethiopia who reported that common two to three days of watering.

\section{Housing system}

Housing is one of the major goat husbandry practices that protect them from extreme temperature, rain, wind, predators, and theft by reducing stress and making management easier. The housing system in the current study concurs with the report of Dhaba et al. (2012) and Yadeta (2016) in western Ethiopia who reported that adjoin house, separately constructed house, and main house with a family. However, it disagrees with the report of Mahilet (2012) in east Hararghe that $79.9 \%$ of the farmers kept their goats in the main family house; and Alubel (2015) in Ziquala district, majority (83.82\%) of farmers confine their goats without roof and (18.18\%) confine their goats in family house. Similar to the current findings, Dhaba et al. (2012) reported that farmers in Ilu Aba Bora zone sheltered goat and sheep together (47\%) and goat separately (53\%). In contrast, Alubel (2015) reported that $61 \%$ of respondents in Lay Armachiho district housed their goat together with other animals, while majority of (>70\%) respondents in Ziquala and Tanqua Abergelle districts did not house goat together with other animals except sheep. The current result bespeaks that in all study districts all sex and age groups of goats were housed together except newborn kids. The result agrees with the report of Mahilet (2012) and Alubel (2015) that all sex and age group of goats were housed together at night except newborn kids. Focal group discussion indicated that for the first two weeks kids were kept on temporary pens (bedding materials) to 
reduce physical injuries and enables them kept dry, clean and warm at night. Some farmers keep dam and kids indoor for at least the first two days of kidding and give care for both which may increase kid survival. Such practice is important to strengthen association between kids and dams and avoids trampling on newborn by other animals. Hundie and Geleta (2015) also reported the practice in western Ethiopia.

\section{Fattening practices}

The difference on goat fattening practices between districts could be resulted from varied farmers management practices and awareness on fattening. Relative to other districts in Nono Benja goat fattening was less common, which might be due to lack of good extension service and awareness. The current finding contradicts with the report of Alefe (2014) in Shebelle zone of southeastern Ethiopia that none of the respondents practiced fattening and Belete et al. (2015) in Bale zone that about $\mathbf{7 9 . 2 \%}$ of the respondents were not practicing fattening. On the other hand, the current finding is lower than that of (Zergaw et al., 2016) who reported $70.4 \%$ of respondents practiced goat fattening for Central highland and Woyto-Guji goat type in Konso and Meta Robi districts of Ethiopia. Significant different between districts on types of feed resources may be resulted from different management system of farmers or availability of different feeds in the districts. According to respondents in Limu Seka district, porridge can increase milk production and decrease fattening duration. Natural pasture, crop residues, and chat gheraba are also reported as a source of feed for goat fattening by Shenkute et al. (2010) in Western Ethiopia and (Belete et al., 2020) in Bale zone. In general, improved feeding and management methods did not support fattening practices of goat in the study area.

\section{Castration practices}

The significant difference between districts on goat castration could be due to lack of awareness on the importance of castration in this district that resulted from weak extension service. The current finding was, lower than (Shenkute et al., 2010) in Western Ethiopia who reported that all HHs in goat dominant areas castrate goat. However, it disagrees with that of Tsigabu (2015) for Nuer zone reported where only $14.45 \%$ of farmers practiced goat castration. Less number of respondents where performing castration at a veterinary clinic by using Burdizo castrator when compared with the report of Dhaba et al. (2012) in which 91\% of the respondents performed castration at veterinary clinics in llu Aba Bora zone. In agreement with the present results, goat castration has been reported in different parts of Ethiopia mainly to improve fattening and obtain more prices (Tegegn et al., 2016; Tegegn and Askale, 2017). Age of castration reported by majority of respondents in the current study was similar with the reports of Dhaba et al. (2012) and Tsigabu (2015) from 6 months to 24 months. The current result revealed that male kids that are more than six months of age were subjected to castration for fattening. Usually, better bucks with good body conformation and having a potential for fattening are subjected to castration at a young age for the market, which results in loss of important gene because of negative selection of breeding males. This will also limit the number of bucks that are available for breeding, which may lead to an increment of inbreeding rate.

\section{Constraints of goat production}

The three primary constraints of goat production were disease, feed shortage and lack of superior genotype in order. Disease problem may have resulted from climatic condition, poor veterinary and limited extension service. Disease and feed shortage were the constraint of goat production as reported by Belete et al. (2015); Fikru and Gebeyew (2015); Tesfahun et al. (2017); Tegegn and Askale (2017) and Beyene et al. (2018) in different places of Ethiopia.

\section{CONCLUSION}

Indigenous goats in the study area are kept in a mixed crop-livestock production system with small flock size. Natural pasture, fallow land, crop residues and other non-conventional feeds were the main feed resources. Rivers are the most important sources of water during dry and wet seasons. Majority of respondents were practiced goat fattening and castration, even if, it varies between districts. The major constraints of goat production were disease, feed shortage and lack of superior genotypes. In general, goat management system practiced in the study areas was traditional in the mixed production system in which indigenous goats were constrained by disease problem and a seasonal shortage of feed.

\section{DECLARATIONS}

\section{Corresponding author}

Email: gutuyemane@gmail.com

\section{Ethics (consent to participate)}

The research article meets all applicable standards with regard to ethics and integrity. As a researcher along with the co-authors, the paper has been submitted with full responsibility, following due ethical procedure, and there is no duplicate publication, fraud or plagiarism.

\section{Authors' contribution}

All authors contributed equally on drafting and organizing the manuscript and approved the final manuscript. 
Availability of data

Data sharing is not applicable to this article.

Consent to publish

Not applicable.

Conflict of interest

Authors certify that there is no competing interest with any financial organization concerning the material discussed in the manuscript.

\section{Acknowledgement}

The authors would like to thank zone and districts Livestock and Fishery resource office for facilitating and supporting the study as well as the study communities those participated in an interview.

\section{REFERENCES}

Abegaz S (2014). Design of community based breeding programs for two indigenous goat breeds of Ethiopia. PhD thesis. Vienna, Austria: University of Natural Resources and Life Sciences, Vienna. Google Scholar ; Link

Abraham H, Gizaw S and Urge M (2017). Begait Goat Production Systems and Breeding Practices in Western Tigray, North Ethiopia. Open Journal of Animal Sciences, 7: 198-212. Google Scholar ; DOI: http://doi.org/10.4236/ojas.2017.72016

Abraham H, Gizaw S and Urge M (2018). Identification of breeding objectives for Begait goat in western Tigray, North Ethiopia. Tropica Animal Health and Production,50:1887-1892. Google Scholar ; http://doi.org/10.1007/s11250-018-1640-5

Alefe T (2014). Phenotypic Characterization of Indigenous Goat types and their Production System in Shabelle Zone, South Eastern Ethiopia. MSc Thesis Submitted to the School of Animal and Range Sciences, School of Graduate Studies, Haramaya University, Ethiopia.P.112. Google Scholar

Alubel A (2015). On-farm phenotypic characterization and performance evaluation of Abergelle and Central highland goat breeds as an input for designing community-based breeding program. MSc Thesis Submitted to the School Of Animal and Range Sciences, School Of Graduate Studies, Haramaya University, Ethiopia. 128p. Google Scholar ; Link

Arse G, Feyisa H, Gurmessa U, Merga M \& Girma D (2013). Assessment on challenges and opportunities of goat farming system in Adami Tulu, Arsi Negelle and Fantale districts of Oromia Regional State, Ethiopia. African Journal of Agricultural Research. 8(1): 26-31. Google Scholar ; DOI: https://doi.org/10.5897/AJAR12.1568

Arsham H (2007). Business statistical decision science and systems stimulation Merrie School of business Charles at Mount Royal, Baltimore, Maryland, 2120, University of Baltimore, UAS, Pp. 100. Google Scholar

Belete A, Kefelegn K and Kefena E (2015). Assessment of production and reproduction system of indigenous goat types in Bale Zone, Oromia, Ethiopia. Academia Journal of Agricultural Research 3(12): 348-360. Google Scholar ; DoI: https://doi.org/10.15413/ajar.2015.0143

Belete A, Kefelegn K, Kefena E (2020). On Farm Phenotypic Characterization of Indigenous Goats Types in Bale zone, Oromia Region, Ethiopia. International Journal of Livestock Production (in press). Link

Beyene A, Alilo AA, Mola M (2018). Assessment of sheep and goat (Small ruminants) production system in Esera district of Dawro zone, Southern Ethiopia. Journal of Advanced Dairy Research. 6:215. Google Scholar ; DOI: https://doi.org/10.4172/2329-888X.1000215

CSA (2018). Agricultural sample survey. Report on livestock and livestock characteristics. The Federal Democratic Republic of Ethiopia Central Statistical Agency (CSA). Vol. II. Report on Livestock and livestock characteristics (private peasant holdings). Statistica Bulletin 587, Addis Ababa, Ethiopia, April 2018. Google Scholar

Chebo C and Alemayehu K (2012). Trends of cattle genetic improvement programs in Ethiopia: Challenges and opportunities. Livestock Research for Rural Development, 24: Article \#109. Google Scholar ; Link

Dhaba U, Belay D, Solomon D and Tolamariam T (2012). Sheep and goat production systems in llu Aba Bora zone of Oromia Regiona State, Ethiopia: Feeding and management strategies. Global Veterinaria 9(4):421-429. Google Scholar ; Link

FAO (2012). Draft Guidelines on Phenotypic Characterization of Animal Genetic Resources. Commission on Genetic Resources for Food and Agriculture. Thirteenth, Regular session, Rome, 18-22 July 2012. Link

FAOSTAT (2016). Food and agricultural organization of the United Nations, statistical division. Google Scholar ; Link

Fikru S and Gebeyew K (2015). Sheep and goat production system in Degehabur zone, Eastern Ethiopia: Challenge and Opportunities Journal of Advances in Dairy Research, 3:134. Google Scholar ; Link

Hundie D and Geleta G (2015) Assessment on production situation and breeding practices of Horro sheep under traditional management in Horro Guduru and East Wollega zone, West Ethiopia. Global Journal of Animal Breeding and Genetics 3: 146-152. Google Scholar Link

Mahilet D (2012). Characterization of Hararghe Highland Goat and their Production System in Eastern Hararghe. MSc thesis, Submitted to the School of Graduate Studies of Haramaya University, Ethiopia. Google Scholar ; Link

Mohammed H., Yisihak K. \& Meseret M. 2016. Characterization of Livestock Production System in three Selected Districts of Jimma Zone, Southwest Ethiopia. Journal of Reproduction and Infertility 7 (2): 47-62. Google Scholar ; Link

Molla M (2020). Conservation-based breeding program for indigenous sheep breeds in Ethiopia: the way forward. Online Journal of Anima and Feed Research, 10(1): 17-24. Google Scholar ; Link

Monau P, Raphaka K, Chimboza PZ and Gondwe T (2020). Review paper on sustainable utilization of indigenous goats in Southern Africa. Diversity, 12: 20. Google Scholar ; DOI: https:// doi.org/10.3390/d12010020

Shenkute B, Legasse G, Tegegne T and Hassen H (2010). Small ruminant production in coffee-based mixed crop-livestock system of Western Ethiopian Highlands: Status and prospectus for improvement. Livestock research for Rural Development. Volume 22, Article \#186. Google Scholar ; Link

Sheriff $\mathrm{O}$ and Alemayehu K (2018). Small ruminant production systems and breeding programs in Ethiopia: achievements, challenges and lessons learned: a Review. Online Journal of Animal and Feed Research, 8(3): 59-73. Google Scholar ; Link 
Shewangzaw A, Aschalew A, Addis G, Malede B and Assemu T (2018). Small ruminant fattening practices in Amhara region, Ethiopia. Agriculture \& Food Security, 7:64. Google Scholar ; DOI: https://doi.org/10.1186/s40066-018-0218-9

Skapetas B, and V. Bampidis (2016). Goat production in the world: present situation and trends. Livestock Research for Rural Development, 28: 11. Google Scholar ; Link

Solomon AK, Mwai O, Grum G, Haile A, Rischkowsky B, Solomon G and Dessie T(2014). Review of goat research and development projects in Ethiopia. ILRI project report. Nairobi, Kenya: International Livestock Research Institute. Google Scholar ; Link

SPSS Version, 24.0. (2016). Software Package for Social Sciences for Window, SPSS Inc. USA. Link

Tegegn F and Askale G/M (2017). Goat production system and breeding practices in pastoral and mixed production system in southwestern part of Ethiopia. Agricultural and biological Journal of North America, 8(3): 67-71. Link

Tegegn F, Kefyalew A \& Solomon A. (2016). Characterization of goat production systems and trait preferences of goat keepers in Bench Maji zone, southwestern Ethiopia. African Journal of Agricultural Research, 11(30): 2768-2774. Google Scholar ; DOI: https://doi.org/10.5897/AJAR2015.10170

Tesfahun B, Kebede K and Effa K (2017). Traditional goat husbandry practices under pastoral systems in South Omo zone, southern Ethiopia. Tropical Animal Health and Production 49(3) 625-632. Google Scholar ; DOI: https://doi.org/10.1007/s11250-017-1240$\underline{9}$

Teshager A, Belay D and Taye T. (2013). Socioeconomic and Farm Characteristics of Smallholder Cattle Producers in Ilu Aba Bora Zone of Oromia Regional State, South Western Ethiopia. Global Veterinaria, 10(5): 607-612. Google Scholar ; Link

Tsigabu G 2015. Phenotypic Characterization of Goat Type and Their Husbandry Practices in Nuer Zone of Gambella People Regional State, South Western Ethiopia. M.Sc. Thesis presented to Haramaya University, Dire Dawa, Ethiopia. Link

Yadeta N (2016). Production and Reproduction Performances, Producers' Trait Preferences and Marketing System of Small Ruminants in Ada Barga and Ejere Districts of West Shoa Zone, Ethiopia, M.Sc. Thesis, Jimma University, Ethiopia. Google Scholar ; Link

Yemane G, Melesse A and Taye M (2020). Characterization of indigenous goat population by applying morphometrical traits and structural indices. Journal of Veterinary Research Advances, 02(01): pp. 22-31. Link

Zergaw N, Dessie T, and Kefelegn K. (2016). Description of production system and on-farm phenotypic characterization of Central Highland and Woyto-Guji goat breeds in Ethiopia. Animal Genetic Resources, 58:43-51, Google Scholar ; Link 